\title{
ANALISIS FAKTOR YANG BERHUBUNGAN DENGAN KECEMASAN PADA MAHASISWA PROGRAM STUDI DIII KEPERAWATAN AKPER DHARMA WACANA METRO ANGKATAN XXIII SAAT PERTAMA TINGGAL DI ASRAMA
}

\author{
Janu Purwono \\ Dosen Akper Dharma Wacana Metro
}

\begin{abstract}
Abstrak
Latar Belakang: Kecemasan adalah sebuah emosi dan pengalaman subyektif dari seseorang. Kecemasan juga dapat diartikan suatu keadaan yang membuat seseorang tidak nyaman dan terbagi dalam beberapa tingkatan. Jadi cemas berkaitan dengan perasaan yang tidak pasti dan tidak berdaya.Tujuan penelitian adalah untuk mengetahui faktor-faktor yang berhubungan dengan kecemasan mahasiswa program studi DIII Keperawatan Akper Dharma wacana Metro Angkatan XXIII saat pertama tinggal di asrama

Metode: Jenis penelitian ini bersifat kuantitatif dengan pendekatan Studi Cross Sectional. Jumlah sampel yang digunakan sebanyak 112 responden. Data diperoleh dengan tehnik wawancara menggunakan kuesioner. Analis data menggunakan Uji Chi square, dengan tingkat kepercayaan 95\% dan multipel regresi logistik.

Hasil: penelitian menunjukkan bahwa ada hubungan variabel tempat tinggal ( $p$-value $=0,028$ ), hubungan interpersonal ( $p$-value $=0.028)$, penyesuaian diri $(p$-value $=0,019)$ dengan kesemasan, dan tidak ada hubungan persepsi makanan $(p$-value $=1,000)$ dan tekanan kelompok $(p$-value $=0,131)$. Faktor yang paling dominan berhubungan dengan kecemasn adalah penyesuaian peran diri $(\mathrm{OR}=2,012)$.

Kesimpulan: Tempat tinggal, hubungan interpersonal, penyesuaian diri berhubungan dengan kecemasan pada mahasiswa Akper Dharma Wacana Metro
\end{abstract}

Kata Kunci : Tempat tinggal, hubungan interpersonal, penyesuaian peran diri, kecemasan

\begin{abstract}
Background: Anxiety is an emotional and subjective experience of a person. Anxiety can also be interpreted a condition that makes a person uncomfortable and divided into several levels. So anxiety associated with feelings of uncertainty and not berdaya.Tujuan study is to determine the factors associated with anxiety student of Nursing Nursing DIII Dharma discourse Force XXIII Metro first time staying in a dorm.

Methods: This research is a quantitative approach Cross Sectional Study. The samples used by 40 respondents. Data were obtained by interview techniques using questionnaires. The data were analyzed using Chi-square test, with a confidence level of $95 \%$ and multiple logistic regression.

Results: The study showed that there is a relationship variables residence (p-value $=0.028$ ), interpersonal relationships ( $\mathrm{p}$-value $=0.028)$, the adjustment $(\mathrm{p}$-value $=0.019)$ with anxiety, and no relationship perception of food $(\mathrm{p}$-value $=1.000)$ and pressure groups $(\mathrm{p}$-value $=0.131)$. The most dominant factor related to anxiety is the role of self-adjustment $(\mathrm{OR}=2.012)$.

Conclusion: A place to stay, interpersonal relationships, self-adjustment associated with anxiety on Nursing student Dharma Wacana Metro
\end{abstract}

Keywords: residence, interpersonal relationships, self-adjustment role, anxiety 


\section{Latar Belakang}

Penyesuaian diri merupakan salah satu persyaratan penting bagi terciptanya kesehatan mental remaja. Banyak remaja yang menderita dan tidak mampu mencapai kebahagiaan dalam hidupnya karena ketidakmampuannya dalam menyesuaikan diri ${ }^{1}$.

Setiap individu memiliki reaksi yang bersifat individual dalam menghadapi suatu keadaan diantaranya kecemasan. Kecemasan adalah suatu respon emosional tanpa objek khusus yang ditimbulkan oleh semua pengalaman-pengalaman baru yang tidak diketahui dan mendahuluinya seperti ; masuk sekolah, memulai pekerjaan baru dan melahirkan seorang bayi ${ }^{2}$.

Kecemasan adalah sebuah emosi dan pengalaman subyektif dari seseorang. Kecemasan juga dapat diartikan suatu keadaan yang membuat seseorang tidak nyaman dan terbagi dalam beberapa tingkatan. Jadi cemas berkaitan dengan perasaan yang tidak pasti dan tidak berdaya ${ }^{3}$.

Respon yang adaptif dari kecemasan dapat memotivasi individu untuk belajar dan menghasilkan pertumbuhan dan kreatifitas, sementara respon maladaptif akan menyebabkan individu mengalami kehilangan kendali, tidak mampu melakukan sesuatu walaupun dengan pengarahan ${ }^{2}$.

Tingkat kecemasan menurut Stuart dan Sundeen terdiri dari cemas ringan, sedang, berat dan panik, tingkat kecemasan ringan dan sedang merupakan respon adaptif, sedangkan tingkat kecemasan berat dan panik merupakan respon maladaptif ${ }^{2}$.
Sebagaimana yang diungkapkan oleh Sunaryo bahwa ciri-ciri psikologik dari kecemasan meliputi; kehawatiran, gugup, tegang, cemas, rasa tidak aman dan lekas terkejut. Kondisi fisik yang dialami oleh mahasiswa (1-2 bulan) awal masuk asrama menunjukan bahwa mahasiswa menjadi susah untuk tidur, jantung berdebar-debar, tangan berkeringat dan gangguan fisik lainnya berupa capek dan letih ${ }^{4}$.

Tingkat kecemasan menurut Kusumawati terdiri dari cemas ringan, sedang, berat dan panik, tingkat kecemasan ringan dan sedang merupakan respon adaptif, sedangkan tingkat kecemasan berat dan panik merupakan respon maladaptif ${ }^{3}$.

Penelitian tentang kecemasan pada mahasiswa Fakultas Psikologi Universitas Muhammadiyah Malang Angkatan 2005-2006 oleh Sohib menunjukan bahwa terdapat kecemasan menghadapi lingkungan baru mahasiswa Fakultas Psikologi Umum Angkatan 2005-2006 adalah 14 orang (10,7 \%) dan sisanya 117 orang $(89,3 \%)$ mempunyai kecenderungan tinggi ${ }^{5}$.

Sedangkan hasil penelitan yang dilakukan pada mahasiswa Akper Dharma wacana Metro XXII oleh purwono pada 119 responden peneliti mendapatkan bahwa kondisi psikis dan fisik mahasiswa (1-2 bulan) masuk awal di asrama Akademi Keperawatan Dharma wacana Metro menunjukan adanya 95 orang responden $(87 \%)$ merasa perasaan cemas ringan, 13 orang responden (12\%) merasa perasaan cemas sedang, dan 1 orang responden $(1 \%)$ merasa perasaan cemas berat ${ }^{6}$. 
Melihat kondisi yang terjadi pada mahasiswa DIII Keperawatan Akper Dharma Wacana angkatan XXII adanya tanda dan gejala kecemasan (1-2 bulan) tawal tinggal di asrama karena dianggap merupakan suatu kondisi yang baru bagi mahasiswa. Dari fenomena yang terjadi maka peneliti tertarik untuk meneliti analisis faktor yang berhubungan dengan kecemasan pada mahasiswa program studi DIII Keperawatan Akper Dharma wacana Metro Angkatan XXIII saat pertama tinggal di asrama.

\section{Metode Penelitian}

Jenis penelitian adalah kuantitatif yang dilakukan dengan survey. Penelitian ini dilakukan secara analitik observasional, yaitu untuk menganalisis faktor-faktor yang berhungan dengan kecemasan mahasiswa Akper Dharma Wacana Metro. Penelitian ini dilakukan di Program studi DIII Akper Dharma wacana Metro. Rancangan penelitian yang digunakan dalam penelitian ini adalah penelitian explanatori dengan pendekatan Studi Cross Sectional.

Populasi penelitian adalah mahasiswa angkatan XXIII Akper Dharma Wacana Metro yang berjumlah 113 responden.

Pengambilan sampel menggunakan metode Total sampling. Variabel penelitian ini terdiri dari variabel independen dan variabel dependen yaitu: variabel independen: Tempat tinggal, hubungan interpersonal, penyesuaian diri, Tempat tinggal, hubungan interpersonal, penyesuaian diri, persepsi makanan, tekanan kelompok sedangkan variabel dependennya penelitian ini adalah kecemasan.

Teknik Pengumpulan data dari responden dengan menggunakan kuesioner terstruktur. Analisa data menggunakan analisa univariat . Analisa suatu variabel dengan menggunakan tabel distribusi frekwensi. Untuk menyimpulkan ada tidaknya hubungan antara dua variabel dilakukan uji Kai Kuadrat/Chi Square.

\section{Hasil Penelitian Analisis Univariat}

Tabel 1

Distribusi Frekuensi Responden Berdasarkan Usia

\begin{tabular}{lll}
\hline Variabel & Jumlah & $\%$ \\
\hline Usia & & \\
$16-20$ tahun & 110 & 97,34 \\
$21-25$ tahun & 3 & 2,66 \\
Jumlah & 113 & 100 \\
& & \\
\hline
\end{tabular}

Berdasarkan tabel 1 di atas, dapat diketahui bahwa dari 113 responden sebagian besar berumur $\leq 20$ tahun $(97,34 \%)$.

Tabel 2 Distribusi Frekuensi Responden
Berdasarkan Jenis Kelamin

\begin{tabular}{lll}
\hline Variabel & Jumlah & $\%$ \\
\hline Jenis Kelamin & & \\
Lak-laki & 34 & 30,08 \\
Perempuan & 79 & 69,92 \\
Jumlah & 113 & 100 \\
\hline
\end{tabular}

Berdasarkan tabel 2 diatas, dapat diketahui bahwa dari 113 responden responden perempuan lebih banyak yaitu mencapai 79 orang $(69,92 \%)$. 


\section{Analisa Bivariat}

Hasil uji statistik analisis bivariat untuk mengetahui hubungan variabel independen dengan kejadian kecemasan melalui uji chi square dengan $a=0,05$ diperoleh hasil faktorfaktor yang berhubungan secara bermakna yaitu persepsi

tempat

tinggal

$(\mathrm{p}=0,028 ; \mathrm{OR}=3.386)$,hubungan interpersonal $(\mathrm{p}=0,028 ; \mathrm{OR}=3.386)$, penyesuaian peran diri $(\mathrm{p}=0,019 ; \mathrm{OR}=2.690)$, sedangkan faktor yang tidak berhungan adalah persepsi makanan $(\mathrm{p}=1,000)$, dan tekanan kelompok $(\mathrm{p}=0,131)$ (lihat tabel 3).

Tabel 3

Analisis faktor berhubungan dengan Kecemasan

\begin{tabular}{|c|c|c|c|c|c|c|}
\hline \multirow[b]{2}{*}{ No } & \multirow[b]{2}{*}{ Variabel } & \multicolumn{2}{|l|}{ Kecemasan } & \multirow{2}{*}{$\Sigma$} & \multirow{2}{*}{ p-value } & \multirow{2}{*}{ OR } \\
\hline & & $\begin{array}{l}\text { Tidak Cemas } \\
\text { n }(\%)\end{array}$ & $\begin{array}{l}\text { Cemas } \\
\text { n }(\%)\end{array}$ & & & \\
\hline 1 & $\begin{array}{l}\text { Persepsi Makanan } \\
\text { a.Baik } \\
\text { b.Tidak baik } \\
\text { Jumlah }\end{array}$ & $\begin{array}{l}15(48,4) \\
40(48,8) \\
55(48,7)\end{array}$ & $\begin{array}{l}16(51,6) \\
42(51,2) \\
58(51,3)\end{array}$ & $\begin{array}{l}31 \\
82 \\
113(100)\end{array}$ & 1,000 & \\
\hline 2 & $\begin{array}{l}\text { Tempat tinggal } \\
\text { a.Baik } \\
\text { b.Tidak baik } \\
\text { Jumlah }\end{array}$ & $\begin{array}{r}49(54,4) \\
6(26,1) \\
55(48,7)\end{array}$ & $\begin{array}{l}41(45,6) \\
17(73,9) \\
58(51,3)\end{array}$ & $\begin{array}{l}90 \\
23 \\
113(100)\end{array}$ & 0,028 & 3.386 \\
\hline 3 & $\begin{array}{l}\text { Hubungan Interpersonal } \\
\text { a.Mudah } \\
\text { b.Tidak mudah } \\
\text { Jumlah }\end{array}$ & $\begin{array}{r}49(54,4) \\
6(26,1) \\
55(48,7)\end{array}$ & $\begin{array}{l}41(45,6) \\
17(79,9) \\
58(51,3)\end{array}$ & $\begin{array}{l}90 \\
23 \\
113(100)\end{array}$ & 0,028 & 3.386 \\
\hline 4 & $\begin{array}{l}\text { Penyesuain peran diri } \\
\text { a.Mudah } \\
\text { b.Tidak mudah } \\
\text { Jumlah }\end{array}$ & $\begin{array}{l}29(63,0) \\
26(38,8) \\
55(48,7)\end{array}$ & $\begin{array}{l}17(37,0) \\
41(61,2) \\
58(51,3)\end{array}$ & $\begin{array}{l}46 \\
67 \\
113(100)\end{array}$ & 0,019 & 2.690 \\
\hline 5 & $\begin{array}{l}\text { Tekanan Kelompok } \\
\text { a.Ada } \\
\text { b.Tidak ada } \\
\text { Jumlah }\end{array}$ & $\begin{array}{l}38(55,1) \\
17(38,6) \\
55(48,7)\end{array}$ & $\begin{array}{l}41(44,9) \\
27(61,4) \\
58(51,3)\end{array}$ & $\begin{array}{l}69 \\
44 \\
113(100)\end{array}$ & 0,131 & \\
\hline
\end{tabular}

\section{Analisa Multivariat}

Berdasarkan analisa multivariat menggunakan tehnik regresi linier terlihat 1 variabel yaitu penyesuaian peran diri yang mempunyai nilai $\mathrm{p}$-value $>0,05$ hasil analisis variabel yang paling dominan adalah penyesuaian peran baru dengan OR sebesar 2.012 .

\section{Pembahasan}

1.Distribusi Frekwensi Tentang Umur, Jenis Kelamin

Umur atau usia adalah masa hidup responden yang dinyatakan dalam tahun sesuai dengan pernyataan responden. Jenis kelamin adalah jenis kelamin responden saat mengadakan penelitian. Pendidikan adalah suatu kegiatan atau proses pembelajaran untuk mengembangkan atau 
meningkatkan kemampuan tertentu sehingga sasaran pendidikan itu dapat berdiri sendiri ${ }^{6}$.

Hasil analisis univariat menunjukkan bahwa responden yang berumur diatas 16-20 tahun (97,94\%), jenis kelamin perempuan $(69,98 \%)$. Hal ini menunjukkan bahwa mahasiswa Akper Dharma wacana yang mengalami kecemasan adalah bejenis kelamin perempuan, berumur dibawah 20 tahun.

Berdasarkan uraian diatas maka dapat disimpulkan bahwa mahasiswa Akper Dharama wacana Metro yang mengalami kecemasan adalah berjenis kelamin perempuan, berumur dibawah 20 tahun.

Kondisi ini menurut peneliti kecemasan pada mahasiswa dikarenakan persepsi makanan yang tidak baik, persepsi tempat tinggal yang tidak baik, hubungan interpersonal yang tidak baik, penyesuaian peran diri yang tidak baik dan adanya tekanan kelompok.

\section{Hubungan Persepsi Makanan dengan Kecemasan}

Penampilan makanan adalah penampakan yang ditimbulkan oleh makanan yang disajikan. Penampilan ini meliputi warna, bentuk makanan, besar porsi, dan cara penyajian. Sedangkan rasa makanan adalah rasa yang ditimbulkan dari makanan? ${ }^{7}$.

Hasil analisis bivariat menunjukkan bahwa persepsi makanan tidak terbukti berpengaruh secara signifikan dengan kecemasan dengan $p$ value $=1.000(\mathrm{p}<0,05)$, maka dapat disimpulkan bahwa tidak ada hubungan yang bermakna antara faktor persepsi makanan dengan kecemasan mahasiswa di asrama Akper Dharma wacana Metro.
Hasil penelitian tidak sejalan yang dilakukan oleh Rohmawati yang menunjukkan adanya hubungan yang bermakna antara tingkat kecemasan dengan status gizi $(\mathrm{p}<0,05)$, subyek dengan tingkat kecemasan sedang cenderung memiliki status gizi lebih $(\mathrm{OR}=3,54)$ dan status gizi kurang $(\mathrm{OR}=2,29)$. Ada hubungan yang bermakna antara tingkat kecemasan sedang dengan asupan makan lebih $(\mathrm{p}<0,001 ; \mathrm{OR}=6,22)^{8}$.

Dari uraian diatas menunjukkan bahwa ketika seorang responden mempunyai persepsi makanan baik dipengaruhi juga oleh kemampuan adaptasi di asrama yang tinggi. Semakin tinggi adaptasi dan persepsi makanan seseorang maka akan semakin baik persepsi tentang makanan seseorang serta tidak menyebabkan kecemasan. Demikian juga semakin rendah persepsi tentang makanan seseorang maka akan semakin baik persepsi tentang makanan seseorang dan menyebabkan kecemasan. Pada responden menunjukkan bahwa persepsi makanan di asrama akper dharma wacana baik sehingga tidak menyebabkan kecemasan.

\section{Hubungan Persepsi Tempat Tinggal dengan Kecemasan}

Hasil analisis bivariat menunjukkan bahwa persepsi tempat tinggal terbukti berpengaruh secara signifikan dengan kecemasan dengan hasil yang dapat dilihat pada uji chi square dengan $p$ value $=0.028(\mathrm{p}<0,05)$, maka dapat disimpulkan bahwa ada hubungan yang bermakna antara faktor persepsi tempat tinggal dengan kecemasan mahasiswa di asrama Akper Dharma wacana Metro.

Hasil penelitian ini sejalan dengan penelitian yang dilakukan oleh Rahmatika yang menyatakan 
bahwa ada hubungan yang bermakna antara kecemasan perpisahan dengan orang tua dengan motivasi belajar pada santri pelajar di pondok pesantren assidikkiyah. Hal tersebut ditunjukkan dengan $p$-value $=0,020<\alpha 0,05^{9}$.

Dari uraian diatas menunjukkan bahwa ketika seorang responden mempunyai kemampuan persepsi tempat tinggal dengan baik dipengaruhi juga oleh kemampuan adaptasi di asrama yang tinggi. Semakin tinggi/baik persepsi tempat tinggal seseorang yang tinggal di asarama akper dharma wacana metro maka tidak akan menyebabkan kecemasan. Demikian juga semakin rendah/kurang baik persepsi tentang tempat tinggal di asrama akper dharma wacana metro pada responden maka akan semakin menyebabkan kecemasan. Pada responden menunjukkan bahwa persepsi tempat tinggal di asrama akper dharma wacana tidak baik sehingga menyebabkan kecemasan.

\section{Hubungan Interpersonal dengan Kecemasan}

Hubungan interpersonal adalah saat kita sedang melakukan komunikasi dengan orang lain yang bukan hanya menyampaikan informasi, tetapi juga menentukan kadar hubungan interpersonal ${ }^{10}$.

Hasil analisis bivariat menunjukkan bahwa hubungan interpersonal terbukti berpengaruh secara signifikan dengan kecemasan dengan = $0.028(\mathrm{p}<0,05)$. Pada hasil analisis juga didapatkan nilai OR sebesar 3.386 artinya mahasiswa yang mempunyai persepsi hubungan interpersonal tidak mudah akan meningkatkan kecemasan sebesar 3.386 kali dibandingkan dengan mahasiswa yang mempunyai persepsi hubungan interpersonal mudah.

Hasil penelitian ini sejalan dengan penelitian yang dilakukan oleh Rosiana bahwa terdapat
51,1\% mahasiswa faskultas psikologi Unisba angkatan 2005 kurang mampu melakukan hubungan interpersonal dengan lingkungan sekitarnya ${ }^{11}$.

Dari uraian diatas menunjukkan bahwa ketika seorang responden mempunyai kemampuan hubungan interpersonal dengan baik dipengaruhi juga oleh kemampuan adaptasi di asrama yang tinggi. Semakin tinggi adaptasi dan kemampuan melakukan hubungan interpersonal seseorang maka semakin baik hubungan interpersonal seseorang dan tidak menyebabkan kecemasan. Demikian juga semakin rendah adaptasi dan kemampuan hubungan interpersonal seseorang maka akan semakin tidak baik hubungan interpersonal seseorang dan menyebabkan kecemasan. Pada penelitian ini responden menunjukkan bahwa hubungan interpersonal di asrama akper dharma wacana tidak baik sehingga menyebabkan kecemasan.

\section{Hubungan Penyesuaian Peran diri dengan Kecemasan}

Menurut Lawton berpendapat bahwa siswa yang mampu menyesuaikan diri dengan baik akan mengetahui kapan saat harus belajar dan kapan saatnya harus bermain dan segera mengatasi permasalahan yang menuntut penyelesaian ${ }^{12}$. Terujinya hipotesis dalam penelitian ini didukung oleh penelitian Rizvy yang mengungkapkan bahwa tingkat kecemasan yang tinggi dan kemampuan adaptasi yang rendah dapat mendorong ke arah prokrastinasi akademik ${ }^{13}$.

Hasil analisis bivariat menunjukkan bahwa penyesuaian peran diri terbukti berpengaruh secara signifikan dengan kecemasan dengan $p$ value $=0.019(\mathrm{p}<0,05)$. Pada hasil analisis juga didapatkan nilai OR sebesar 2.690 artinya 
mahasiswa yang mempunyai penyesuaian diri tidak mudah akan meningkatkan kecemasan sebesar 3.386 kali dibandingkan dengan mahasiswa yang mempunyai penyesuaian diri mudah.

Hasil penelitian ini sejalan dengan penelitian yang dilakukan oleh Naili bahwa hubungan yang signifikan antara penyesuaian diri dengan prokrastinasi akademik. Hal tersebut ditunjukkan dengan $p$-value $=0,000<\alpha 0,05^{14}$.

Dari uraian diatas menunjukkan bahwa ketika seorang responden mempunyai kemampuan penyesuaian diri dengan baik dipengaruhi juga oleh kemampuan adaptasi di asrama yang tinggi. Semakin tinggi adaptasi dan kemampuan diri seseorang maka akan semakin baik penyesuaian peran diri seseorang serta menyebabkan kecemasan. Demikian juga semakin rendah adaptasi dan kemampuan diri seseorang maka akan semakin baik penyesuaian peran diri seseorang dan menyebabkan kecemasan. Pada penelitian ini responden menunjukkan bahwa penyesuaian peran diri di asrama akper dharma wacana tidak baik sehingga menyebabkan kecemasan.

\section{Hubungan Tekanan Kelompok dengan Kecemasan}

Menurut Smith tekanan kelompok diberikan kepada anggota dengan maksud untik memperkecil perbedaan perbedaan yang timbul dalam kelompok karena perbedaan keinginan anggota dan dilakukan oleh orang-orang tertentu yang lebih dominan ${ }^{15}$.

Hasil analisis bivariat menunjukkan bahwa tekanan kelompok tidak terbukti berpengaruh secara signifikan dengan kecemasan dengan $p$ value $=0.131(\mathrm{p}<0,05)$.
Dari uraian diatas menunjukkan bahwa ketika seorang responden mempunyai kemampuan penyesuaian diri dengan baik dipengaruhi juga oleh kemampuan adaptasi di asrama yang tinggi. Semakin tinggi adaptasi dan kemampuan diri seseorang maka akan semakin baik penyesuaian peran diri seseorang serta menyebabkan kecemasan. Demikian juga semakin rendah adaptasi dan kemampuan diri seseorang maka akan semakin baik penyesuaian peran diri seseorang dan menyebabkan kecemasan.

\section{Faktor Yang Paling Dominan Yang Berhubungan Dengan Kecemasan}

Penelitian tentang penyesuaian diri yang dilakukan oleh Anggraini menunjukkan nilai signifikan yang diperoleh variabel kemandirian dengan penyesuaian diri sebesar 0,000. Artinya, nilai signifikan lebih kecil dibanding dengan $\alpha$ (sig $<0,05)$ yang berarti terdapat hubungan signifikan antara kedua variabel, sehingga dapat disimpulkan bahwa terdapat hubungan positif antara variabel kemandirian dan penyesuaian $\operatorname{diri}^{16}$.

Penelitian tentang faktor-faktor yang berhubungan dengan kecemasan resiko terjadinya hipertensi pada seseorang juga telah dilakukan oleh Rahmawan menyatakan bahwa penyesuaian diri menggunakan lima indikator: accepting, preserving, taking, exchanging, biophilous, yang dikategorikan menjadi penyesuaian diri baik dengan nilai $\geq 19,96$, penyesuaian diri buruk $<$ 19,96. Sedangkang tingkat kecemasan dengan indikator fisiologis, psikologis. Dengan pengkategorian $<\alpha 0,05$, dengan demikian maka Ha diterima, artinya pada penelitian ini ada hubungan penyesuaian diri dengan tingkat kecemasan lanjut usia di Karang Werda Semeru Jaya dan Jember Permai Kecamatan Sumbersari, 
Kabupaten Jember. Hasil penelitian ini menjelaskan bahwa penyesuaian diri mempunyai hubungan dengan tingkat kecemasan, apabila lanjut usia bisa menyesuaiankan diri dengan baik, maka sedikit kemungkinan lanjut usia beresiko mengalami kecemasan, namun lanjut usia dengan penyesuaian diri buruk lebih beresiko untuk mengalami kecemasan ${ }^{12}$.

Hasil analisis multivariat menunjukkan bahwa penyesuaian peran diri terbukti berpengaruh secara signifikan dengan kecemasan ( $p$ value $=0,047$ ). Pada hasil analisis juga didapatkan nilai OR sebesar 2,012 artinya responden yang mempunyai penyesuaian diri tidak baik akan meningkatkan kecemasan yang lebih baik sebesar 2,012 kali dibandingkan dengan responden yang memiliki peneyesuaian diri baik pada kecemasan mahasiswa yang pertama tinggal di asrama.

Faktor penyesuaian diri menunjukkan bahwa lebih dominan dibandingkan dengan faktor hubungan interpersonal dan tekanan kelompok. Kondisi ini menurut peneliti disebabkan karena seseorang jika memiliki kemampuan diri yang baik berarti maka tidak akan terjadi kecemasan, demikian juga secara otomatis hubungan interpersoanal dan tekanan kelompok pada diri seseorang juga baik dan positif.

\section{Kesimpulan}

1. Ada hubungan yang bermakna antara tempat tinggal, hubungan interpersonal, penyesuaian diri dengan kecemasan pada mahasiswa Akper Dharma Wacana Metro.

2. Tidak ada hubungan yang bermakna antara persepsi makanan, tekanan kelompok dengan kecemasan pada mahasiswa Akper Dharma Wacana Metro

\section{Daftar Pustaka}

1. Mu'tadin, Z (2002), pengantar pendidikan dan ilmu perilaku kesehatan, Yokyakarta, Andi Offset

2. Stuard \& Sundeen (1995) Keperawatan Jiwa. EGC, Jakarta Alih bahasa : Hamid.S Yani A.

3. Kusumawati $\mathrm{F}$ (2011), Buku ajar keperawatan Jiwa, Salemba Medika

4. Sunaryo. (2004) Psikologi Untuk Keperawatan. EGC, Jakarta.

5. Shohib, M. (2005) "Kecemasan" Melalui www.google.com. (28/01/06).

5. Purwono J, (2014), penelitian. Gambaran tingkat kecemasam mahasiswa Akper Dharma wacana Metro angkatan XXII saat pertama tinggal di asrama, Jurnal wacana Kesehatan 2014

6. Notoatmodjo, S. (2003) Metode Penelitian Kesehatan. Rineka Cipta, Jakarta

7. Drummond KE \& Brefere LM, 2010,

8. Rohmawati N, (2012), Tesis, Tingkat kecemasan, asupan makan, dan status gizi pada lansia di kota yogyakarta, UGM, Yokyakarta

9. Rahmatika, D(2014), skripsi, Hubungan antara kecemasan perpisahan dengan orang tua dengan motivasi belajar pada santri pelajar di pondok pesantren assidikkiyah kebon jeruk Jakarta, Jakarta UIN.

10. Rahmat, 2008.

11.Rosiana D (2005), Prosiding, Penyesuaian akademi mahasiswa tingkat pertama, ISSN 2089-3590

12. Hurlock, E. 1999. Perkembangan Anak. Jilid 2. Jakarta: Erlangga

13. Rachmahana, R.S. 2002. (skripsi), Perilaku Prokrastinasi Akademik Pada Mahasiswa.

14. Naili Z, dkk (2009), hubungan antara penyesuaian diri dengan prokrastinasi akademik siswa sekolah berasrama smp n 3 peterongan jombang, Jurnal Psikologi Undip Vol. 8, No.2, Oktober 2010

15. Smith, Definisi Kelompok

16. Anggraini EN (2002), Skripsi, Hubungan antara kemandirian dengan penyesuaian diri pada mahasiswa baru yang merantau di kota malang, UNIBRAU, Malang 